\title{
The Problem of Using Competence-Based Approach and Information Technologies in Formation of Communicative Competence of the Future Specialists
}

\author{
Madina Murzakhanovna Akeshova ${ }^{1}$, Kamalbek Meirbekovich Berkimbaev ${ }^{2}$, \\ Zhanali Erkinbekovich Daribaev ${ }^{3}$, Gulmira Pernebekovna Meirbekova ${ }^{3}$, \\ Saken Koptleuovich Kurbaniyazov ${ }^{4}$, Zagipa Kyrgyzbaevna Abdikulova ${ }^{5}$ \\ ${ }^{1}$ English Philology Department, A. Yasawi International Kazakh-Turkish University, Turkestan, \\ Republic of Kazakhstan \\ ${ }^{2}$ General Pedagogy and Ethnopedagogy Department, A. Yasawi International Kazakh-Turkish University, \\ Turkestan, Republic of Kazakhstan \\ ${ }^{3}$ Ecology and Chemistry Department, A. Yasawi International Kazakh-Turkish University, Turkestan, \\ Republic of Kazakhstan \\ ${ }^{4}$ Geology Department, A. Yasawi International Kazakh-Turkish University, Turkestan, Republic of Kazakhstan \\ ${ }^{5}$ Natural Science and Energetic Department, A. Yasawi International Kazakh-Turkish University, Turkestan, \\ Republic of Kazakhstan \\ Email: madina_shakh@mail.ru,kamalbek.berkimbaev@yandex.kz
}

Received February $26^{\text {th }}, 2013$; revised March 26 $6^{\text {th }}, 2013$; accepted April $8^{\text {th }}, 2013$

Copyright () 2013 Madina Murzakhanovna Akeshova et al. This is an open access article distributed under the Creative Commons Attribution License, which permits unrestricted use, distribution, and reproduction in any medium, provided the original work is properly cited.

\begin{abstract}
As the result of educational modernization and joining the Republic of Kazakhstan to the Bologna process, A. Yasawi International Kazakh-Turkish University points out as one of its main problem the usage of competence-based approach and information technologies in highly qualified training of the future specialists of international level with professional activity, critical thinking and creativity because of competence-based approach and information technologies emphasize professional education and training of future specialists from practical and pragmatic aspects. Taking into consideration necessary elements of some approaches in pedagogical and psychological sciences such as systematic, personal-oriented and synergetic and others, the importance of competence-based approach as one of necessary base of formation of communicative competence and professional training of future specialists is pointed out. It has professional, pragmatic, humanistic, and practical features, which show its correlation and systematic advantages. Competence-based approach is one of the most effective means of developing methodological and creative thinking activity, professional and cultural norms of behavior, correction of oriented values on the base of educational system, changing activities based on principals of innovative approaches in teaching process of higher education. The results obtained by the use of competence-based approach and information technologies show improvements in formation of communicative competence of the future specialists. Correlation of competence-based approach and information technologies in teaching process show an increase, which points to a significant development and formation of communicative competence of the future specialists. The improvement is also represented in higher average grades of the experimental group and it shows the effectiveness of correlation of competence-based approach and information technologies in formation of communicative competence of the future specialists.
\end{abstract}

Keywords: Information Technologies; Competence-Based Approach; Formation of Communicative Competence

\section{Introduction}

During the modern period there is a formation of uniform world educational space by means of, in particular, harmonization of educational standards, approaches, curricula, qualifiers of specialties in the different countries of the world.

Kazakhstan has accurately defined a reference point on occurrence in world educational space and carries out modernisation of educational system in a context of the international requirements. The Republic of Kazakhstan has entered a strip of successful realization of principles of Bologna process and its adaptation to modern realities. The Bologna declaration regulates construction of uniform educational space in Europe on the basis of introduction of multilevel system of higher education and credit-modular system of training and modernization of the state system of guarantees of quality management formation, working out of new formats of documents on formation and modernization of schemes of a financing of education.

Nowadays one of the actual problems of training of highly 
skilled specialists on the international level and increase the efficiency of educational process at credit-modular teaching system at A. Yasawi International Kazak-Turkish University is information of education and use of competence-based approach and information technologies in professional activity of the future specialists on the basis of competence approach information of communicative competence of the future specialists.

Information of educational system is considered as strategically important paradigm of the Governmental program of educational development of the Republic of Kazakhstan for 2011-2020, confirmed by the President of Kazakhstan, at transition to electronic training the prime problem-maintenance of an education system by highly-skilled personnel (Governmental Program, www.edu.gov.kz).

According to a new Kazakhstan educational paradigm education should be directed on interests of personal development adequate to modern tendencies of social development, and to solve following problems:

- to harmonize relations of the person with the nature through development of a modern scientific picture of the world;

- to stimulate intellectual development and thinking enrichment through development of modern methods of scientific knowledge;

- recognizing that the person lives in a society, to achieve its successful socialization through immersing cultural existence, including technogenic and computerized, environment;

- considering that the modern person lives in conditions of the sated and active information environment, to teach the person to live in its stream, to create preconditions and conditions for continuous self-education;

- in view of integration tendencies of development of a science and techniques, requirement for new level of scientific literacy to create conditions for acquisition of the wide base of education allowing quickly enough to be switched to adjacent areas of professional activity.

Modern education should be complete, for this reason separate disciplines are considered not as set of traditional independent courses, and are integrated into the uniform cycles of disciplines connected by the general criterion function and interdisciplinary communications. One of the basic advantages of the competence-based approach is that learner is perceived not as passive object of educational influence, but as the active one getting higher education. The teacher does not impose to students' personal understanding of a material, and stimulates their independent activity on mastering. Characteristic for new model of training, cooperation lies on the basis of educational activity.

The traditional educational paradigm basically leads to formation dependent learner as the teacher according to the program gives out the planned material focused on the average learner. Learners are not informed on main objectives and have no control over educational process and access to all material that is taught, guided only by instructions of the teacher and the textbook maintenance, studies in the set rate. It is obvious that educational process cannot generate the specialist with creative skills, professional and critical thinking which will be claimed in a modern society.

The educational environment simulated by means of information technologies, allows changing of the situation. The teacher puts the purposes, and forms the informational environment creating conditions for individual work. Presence of means for realization of the purposes and problems of educational process, knowledge of ways of the organization of teaching system and control devices are making components of the computer informational educational environment, which forms independent learner.

\section{Problems Statement}

Educational system of the Republic of Kazakhstan is focused on occurrence in world educational space, therefore the quality of education is considered in the context of conformity of level of received educational services by the world standard and norms. Nowadays the priority is achieved of such quality of training of specialists which gives them the chance to compete on the international laboratory. In the conditions of market relations and complicated requirements to the education, ways of the organization of educational process searches of new reserves of improvement of quality and efficiency of formation of communicative competence of the future specialists are necessary. Changes in social sphere of a society, information of social processes made a paradigm of education which was replaced on competence-based approach in formation of communicative competence of the future specialists (Akeshova, 2012: p. 279)

The organization of educational process with application of informational technology of training, an optimum combination of information-communication technologies and traditional approaches demands the decision of some psychology-pedagogical, methodical and other problems and carrying out of corresponding researches. Having analyzed the literature on research subjects, we have allocated following actual directions of using information-communication technologies in educational process:

- working out of a technique of use of information-communication technologies in teaching system to various disciplines;

- creation of corresponding methodical maintenance;

- an estimation of efficiency of application of informational technology of teaching;

- creation of the unique complex scientifically-methodical approach to a solution of a problem of the usage of information-communication technologies in educational process;

- preparation of the pedagogical staff, capable to carry out training in new conditions and to solve the above-stated problems and tasks.

The urgency of a considered problem is defined, first, by the usage of information-communication technologies assumes presence at the modern, highly skilled expert of new knowledge, abilities, creative style of thinking which will provide necessary social adaptation to changes and guarantee its competitiveness on a labor market; secondly, necessity of perfection of the organization of professional activity of the future specialists in the conditions of information; thirdly, objective requirement of a modern society for preparation of the specialists, capable to be integrated into world information field; fourthly, tendencies of a national educational policy (Berkimbaev et al., 2012: p. 55).

\section{Experimental Design}

Nowadays competence-based approach and information technologies are one of the major factors defining intensive and qualitative development of Kazakhstan educational system. 
Correlation competence-based approach and information technologies in educational process participate:

- the teacher (defines the maintenance of the program of a course, a choice of the educational literature, teaching methods, style of communication etc.);

- pedagogical staff of educational institution (establishes the general requirements to student, kept traditions of given educational institution, the form of mutual relations of pedagogical and student's group etc.);

- the state as public institute (defines the material maintenance as a whole, the social order for formation of that or other system of knowledge and sights).

During the research work we worked out the scheme of correlation of competence-based approach and information technologies in formation of communicative competence of the future specialists in educational process.

To find the optimum decision on a task in view of process of correlation of competence-based approach and information technologies in formation of communicative competence of the future specialists and to receive demanded results of efficiency of correlation of competence-based approach and information technologies in formation of communicative competence of the future specialists we held research work.

The second year students of "Ecology and chemistry" department of Engineering-Pedagogical faculty at A. Yasawi International Kazakh-Turkish University were involved in experiment.

Students of control and experimental group took part in ex- periment. The control group included 42 students, and experimental group 44 students. In both groups after material granting on the theme and its practicing control and total tests were organized and carried out for the mastering, the given material and check of efficiency of process of correlation of competence-based approach and information technologies in formation of communicative competence of the future specialists. After realization of all the activities according to the program and evaluation, the results obtained by the use of these two concepts were compared and statistical parameters for two groups were established.

Based on the analysis of the obtained results, advantages and disadvantages of the correlation of competence-based approach and information technologies in formation of communicative competence of the future specialists in educational process have been defined during the research work, and also efficiency and important features of the correlation of competence-based approach and information technologies in formation of communicative competence of the future specialists in educational process was established and shown in the following figure (Figure 1).

Leaning against methodological approaches and private experience of correlation of competence-based approach and information technologies in formation of communicative competence of the future specialists, we developed the comparative scheme of correlation of competence-based approach and information technologies in formation of communicative compe-

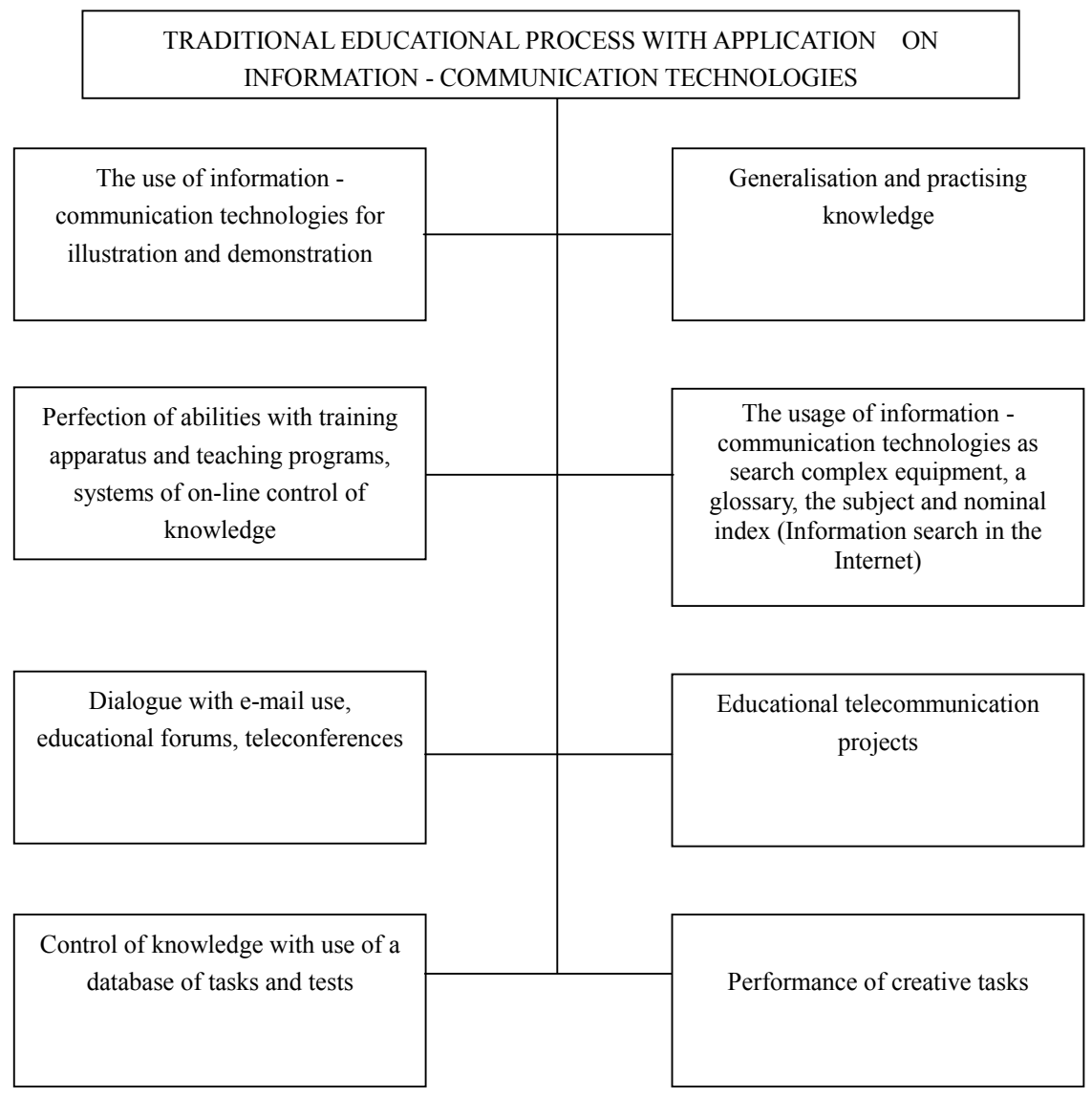

Figure 1.

Correlation of competence-based approach and information technologies in formation of communicative competence of the future specialists. 
tence of the future specialists.

\section{Result and Discussion}

Statistical processing of the results

In order to calculate the effectiveness of correlation competence-based approach and information technology in formation of communicative competence of future specialists in teaching process, the results of students who were taking part in experimental group and the results of students, taking part in control group were compared.

For the proof of degree of formation of communicative competence of future ecologists on the base of correlation of competence approach and information technology it is necessary to show that experimental and control samples have significant distinctions on the chosen indicator - to ability independently to analyze the task, to correlate it with professional work practice. For processing of results of experiment student's t-criterion was used to establish similarities and distinctions of two empirical distributions.

The mathematical package "STATISTICA" was used. By means of Descriptive statistics mode Basics Statistics/Tables of this software were the hypothesis about conformity of samples to normal distribution which was checked up.

On these values for each group the mean score and a standard deviation (Table 1) have been calculated.

For the given quantity are trained $\delta f=44+42=83$. The received empirical value of $t$-criterion equal $t=3376$ exceeds critical for $\rho=.01(t=2,639)$, but it appears less critical for $\rho$ $=.001(\mathrm{t}=3,416)$, hence, it is possible to draw a conclusion on statistically significant distinction of average arithmetic values in two samples and about advantages of the second (experimental) methodical system of correlation of competence-based approach and information technology in formation of communicative competence of future specialists.

The total test spent with students of control and experimental group, is aimed on revealing of efficiency of correlation of competence-based approach and information technology in formation of communicative competence of future specialists. The concept of factor $\mathrm{K}$ relative total mastering of knowledge by students of one group is entered. The factor $\mathrm{K}$ relative total mastering of knowledge by students of one group is calculated under the formula

$$
\mathrm{K} \frac{1 \times \mathrm{N}_{5}+.9 \times \mathrm{N}_{4}+.6 \times \mathrm{N}_{3}+.3 \times \mathrm{N}_{2}}{\mathrm{~N}}
$$

where $\mathrm{K}$-mastering factor, $\mathrm{N}_{5}, \mathrm{~N}_{4}, \mathrm{~N}_{3}, \mathrm{~N}_{2}$ - the quantity of the students, whose answers are estimated accordingly on " 5 " -90 - 100 points, " 4 "-70 - 90 points, " 3 "-50 - 70 points, and $\mathrm{N}-$ total of students in group. The result was estimated on the average by the following parities: "excellent", at $.9 \leq \mathrm{K} \leq 1$;

Table 1.

Means on each group of the average grade and the standard deviation.

\begin{tabular}{ccc}
\hline Numerical characteristics & $\begin{array}{c}\text { 1st sample } \\
\text { (control group) }\end{array}$ & $\begin{array}{c}\text { 2nd sample } \\
\text { (experimental group) }\end{array}$ \\
\hline $\mathrm{n}$ (quantity of students) & 42 & 44 \\
m (average grade) & 3.14 & 3.8 \\
$\begin{array}{c}\sigma \text { (a standard information } \\
\text { technology deviation) }\end{array}$ & .61 & .32 \\
\hline
\end{tabular}

"good", at .7 $\leq \mathrm{K} \leq .9$; "satisfactory", at $.5 \leq \mathrm{K} \leq .7$; "unsatisfactorily", at $\mathrm{K}<.5$.

Results of experiment were processed and tabulated for comparison in the following table (Table 2).

From the received results reflected in (Table 1) and the histogram (Figure 2), and also the obtained results, it is possible to draw a conclusion that experimental work confirmed effectiveness of the process of correlation of competence-based approach and information technology in formation of communicative competence of future specialists.

According to the results of experimental work we can point out that students of experimental group have received high scores in total tests: improvements were observed at students who experienced difficulties in mastering material in the process of correlation of competence-based approach and information technology in formation of communicative competence of future specialists; students' results of experimental group were higher than the results of control group students that proves the effectiveness of correlation of competence-based approach and information technology in formation of communicative competence of future specialists; correlation of competence-based approach and information technology in formation of communicative competence of future specialists improved the progress of professional training of the future specialists.

During the research work we pointed out some advantages of correlation of competence-based approach and information technology in educational process.

Correlation of competence-based approach and information technology at the present stage development allows:

- to construct the open educational system, own trajectory of teaching methods providing to everyone individually (Nefedova, 2005: p. 217);

- to change radically the organization of the process of knowledge by its displacement towards creative thinking system;

- to create an effective control system of information-methodical maintenance of education (Zakharova, 2005: p. $158)$;

- to organize informative and professional work during educational process;

- to use specific properties of the computer, allowing to individualize educational process and to address to essentially new informative means( Nowaczyk, R., 2008: p. 367);

- to construct, develop and improve systems of remote training of various level (Sanaoui et al., 2004: p. 531).

Correlation of competence-based approach and information technology in educational process helps to solve a number of didactic problems:

- to study the phenomena and processes in micro- and a macrocosm, in difficult technical and biological systems on the basis of use of means of computer graphics and computer modeling (Warshauer, M., 2010: p. 477);

- to represent in time scale convenient for studying the vari-

Table 2.

The generalized comparative results of examination of students according to two tests.

\begin{tabular}{ccc}
\hline \multirow{2}{*}{ Groups } & \multicolumn{2}{c}{$\kappa$} \\
\cline { 2 - 3 } & The control test & The total test \\
\hline The control & .74 & .62 \\
The experimental & .88 & .93 \\
\hline
\end{tabular}




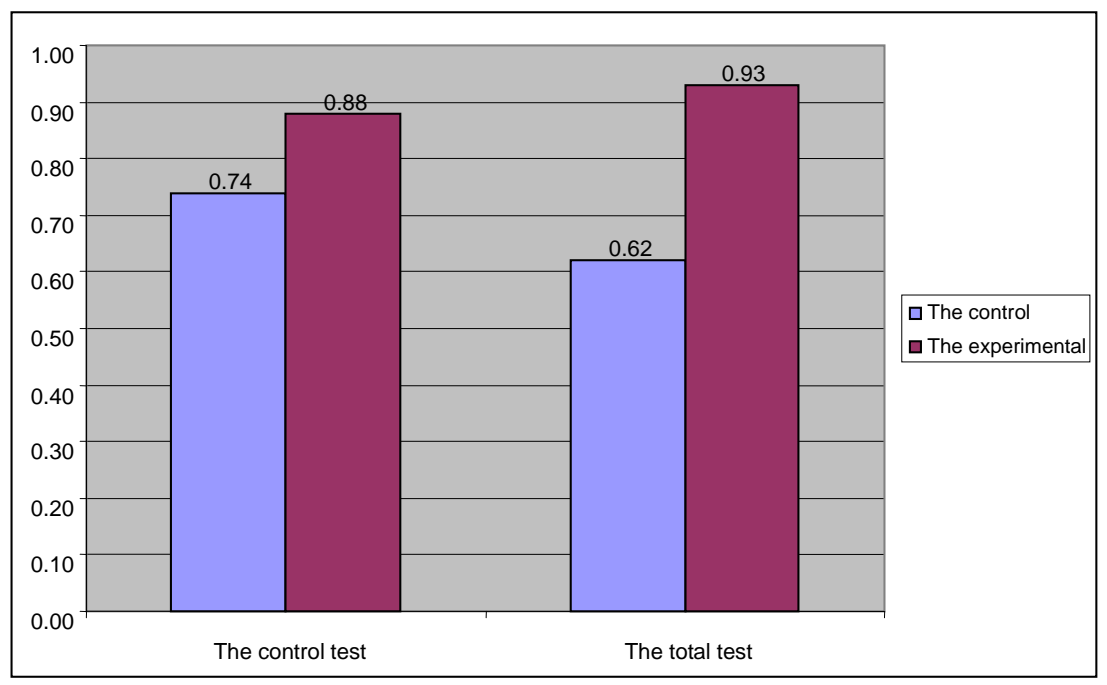

Figure 2.

The generalized comparative results of examination of students according to two tests.

ous social processes really proceeding with very big or very small speed (Stepp-Greany, 2002: p. 175).

Thus knowledge can be received in the declarative way, i.e. focused on a consecutive presentation of portions of the educational information and control of its mastering (electronic textbooks, test and supervising programs, directories and educational databases, educational video films), or procedural, i.e. under construction on the basis of models of studied objects, processes and the phenomena (imitating models, subject-oriented environments and laboratory practical works developed on their basis, training apparatus, game programs).

\section{Conclusion}

In the conclusion it is necessary to notice that now in the world consecutive and steady movement to construction of an information society which urged to create the best conditions for the maximum self-realization of each person is observed (McGrath B., 2008: p. 60).

The carried out analysis of works of many researchers show that the correlation of competence-based approach and information technology in formation of communicative competence of future specialists, for the decision of educational problems, training of the specialists with the critical and creative thinking, capable to function effectively in changing conditions of professional work, becomes the integral component of modern education. In modern educational system the tendency of displacement of accents from mastering of knowledge trained on ability to use the information is traced, to be received by means of information technologies.

Therefore training of specialists should include system to use the given technologies in the future professional work, especially in a context of information of a modern society.

The problem of development of teaching technologies takes an important place in a modern pedagogical science as achievement of peak efficiency of educational process directly depends on presence of competently developed methodical maintenance and definition of a place and a role of information technologies in educational process.

It is necessary to notice that now in the world consecutive and steady movement to construction of an information society which urged to create the best conditions for the maximum selfrealization of each person is observed. The bases for such process are intensive development of information-communication technologies and creation of the developed information educational environment.

Studying and the analysis of a current state of a problem of their use in educational sphere, has shown that there are the numerous works considering possibilities, properties, functions, potential of information technology without an accurate substantiation on the basis of the fact sheet received as a result of practical activities, during experiments. The obvious lack of the researches representing theoretically well-founded methodical recommendations and pedagogical working out on their application is traced. The questions of correlation of competencebased approach and information technology on efficiency of educational process are insufficiently worked. There are no the long and extensive researches showing degree of efficiency and expediency of support of various courses at correlation of competence-based approach and information technology through the Internet by means of telecommunication technologies.

Competence approach promotes communicative competence, willingness to innovate, work in non-standard situations, openness to new, adaptability and mobility.

According to the results of scientific and practical research conducted in A. Yasawi International Kazakh-Turkish University, indicator of formation of the communicative competence of future specialists is readiness for changes, which includes awareness of the situation of the new demand, the development of strategic reasons alleged for consistency of this new, including the development of advanced models of change career and revision of the content of the educational process. Together all counted above provide a consciousness and spontaneous activity of the choice of the projection image of the desired changes or future.

Theoretical and practical study is ongoing and at this stage of study we came to the conclusion that the importance and relevance of the implementation, application and correlation allow the competent approach and information technology to the educational process of the university as the basis of communicative 
competence of the future specialists. In the design of educational process of high school we must take into account the variety of methodological approaches that alter perception, outlook, creative thinking activity of specialists of XXI century and its impact on practice and formation of professional and communicative competence. The quality and effectiveness of training of the future specialists determined the formation of the professional and communicative competence, which may be provided by the presence of language, production, research, sociocultural knowledge based on correlation of competence-based approach and information technology in the educational process of the university.

\section{REFERENCES}

Governmental Program of Development of Education in the Republic of Kazakhstan for 2011-2020. //www.edu.gov.kz

Akeshova, M. M. (2012). Modern teaching methods and techniques in the process of teaching English language of the future ecologists. Materials of the 2nd International Research and Practice Conference, III, 277-281.

Berkimbaev, K. M., Muhamedzhanov, B. K, \& Akeshova, M. M.
(2012). The role of internet-Technologies in formation of communicative competence of the future ecologies. The bulletin. Moscow: Russian University of National Friendship, Informational Education, 50-56.

Zakharova, I.G. (2005). Informational technologies in education. Moscow: Moscow Publishing Center, 204.

McGrath, B. (2008). Partners in learning: Twelve ways technology changes the teacher-student relationship. Technological Horizon in Education, 25, 58-62.

Nefedova, L. V. (2005). Informational Education: Theory and practice. Astana: Euroasian National University, 215-220.

Nowaczyk, R. (2008). Student perception of multimedia in the undergraduate classroom. International Journal of Instructional Media, 25, 367-368.

Sanaoui, R., \& Lapkin, S. (2004). A case study of an FSL senior secondary course integrating computer networking. The Canadian Modern Language Review, 43, 524-552.

Stepp-Greany, J. (2002). Student perceptions on language learning in a technological environment: Implications for the new millennium. Language Learning and Technology, 6, 165-180. http://lit.msu.edu/vol6num 1 /STEPPGREANY/default.html

Warshauer, M. (2010). Computer-mediated collaborative learning: Theory and practice. Modern Language Journal, 81, 470-481. doi:10.1111/j.1540-4781.1997.tb05514.x 